\title{
The Record so Far: a Review of the Literature
}

\author{
Edward Clay and Elisabeth Everitt
}

\section{Introduction}

This brief review of food aid literature aims to illustrate the complexities of the subject and to point the relative newcomer towards the sources of information. The audience envisaged might include a university teacher called on to assemble a course in development studies; a graduate student wishing to examine, for instance, food aid donor policy or the ways in which donated commodities are used; or a government official with new responsibilities for food aid, or workers with one of the many voluntary organisations involved with food aid. The guide does not attempt to be comprehensive, but only, it is hoped, to enable the reader to pursue his enquiries in his chosen field.

The literature is vast. It ranges from the printed book (which may be out of date by the time it is published) to an unpublished memorandum which can contain information or arguments unobtainable elsewhere. In between lie the conference papers and journal articles and printed or mimeographed reports both on food aid specifically and on other topics - aid, trade, agriculture, rural development, nutrition, food distribution, food strategies and regional food security - on which the food aid debate impinges. This article does no more than cover the major themes in brief.

The first place to turn is to published bibliographies and literature reviews, with the caveat that these are unlikely to be up-to-date. A recent annotated bibliography and directory by Cadet [1981] with 445 entries does cover aspects of the literature (at least from US sources) up to 1980; but of 50 entries on food aid in a guide to World Hunger [Ball 1981] only five are as recent as 1979. An earlier annotated bibliography produced for the OECD [Schneider 1975] looked specifically at the effects of food aid on agricultural production in recipient countries, also the theme of a still earlier collection published by the FAO in 1964.

The potential disincentive effect of food aid was 'the single most widely treated issue' in the 1970s, according to Maxwell and Singer in their survey [1979]. Singer's survey carried out for the World Food
Programme [Singer 1978] also treated the question in detail. That this discussion continues today is clear from subsequent literature reviews. These include Stevens's examination [1979] of the effects of food aid in Africa; Wallerstein's Food for War - Food for Peace [1980], which attempts an analysis of 'the political considerations, interests, and objectives that have shaped global food assistance efforts, both bilateral and multilateral, since World War II'; and, more recently, a paper by Clay and Singer [1982] which reviews the literature on the developmental impact of 'programme' food aid, ie supplied for sale or general distribution rather than for specific projects, which accounts for two-thirds of total food aid.

\section{The general discussion}

A succinct overview of the food aid debate can be obtained from reports of seminars and conferences attended by academics, government officials and field workers. The report of a recent seminar at the Institute of Development Studies, Sussex [Clay and Pryer 1982] includes discussion of the wider issues, eg international food security mechanisms, food entitlement schemes and the seasonal dimensions to rural poverty, alongside emergency food aid, donor policy, nutrition projects and programme aid. The report also carries an extensive and up-to-date bibliography. The reports of the regional seminars on improving the developmental effectiveness of food aid, organised by the Agricultural Development Council, focused on Asia [ADC 1981], and Africa [ADC 1982], contain chapters on the macroeconomics of food aid, the formation of human capital, food security, and case studies of national policies in recipient countries. Both the contributed papers and the summaries of discussions are suggestive of the need for more explicit recognition of distinctive regional and country specific issues in food and policy analysis.

The search for effective food policies in developing countries, which often includes food aid as a component, has led to increasing discussion of the need for national and international food security systems. A book edited by Valdes [1981] draws 
together the main strands of the debate, while sources of food insecurity are examined in some depth in a recent World Bank Staff Working Paper [Clay et al 1981], which includes studies of food policy issues in Zambia, Bangladesh and India.

Government food policy and the handling of programme aid in India in the early 1970s, and currently in Bangladesh, have generated a body of controversial 'impact' literature. Schubert [1981] has recently attempted to measure the overall impact of food aid on world malnutrition, but most contributions have been at country level, with particular emphasis on India. Isenman and Singer [1977] drew together the threads of the debate so far, with particular reference to India; and Blandford and von Plocki [1977] provide a valuable review of the problems involved in analysing the disincentive effect in India through quantitative models.

The agencies and organisations which handle food aid generate a body of normative literature on the subject. In 1981 USAID issued a policy discussion paper on Food Aid and Development, and a report to the European Parliament in 1980 on the Community's contribution to the campaign to eliminate hunger in the world was followed by a 'plan of action' issued by the European Commission [1981] to combat world hunger. The UN World Food Council (WFC), which provides an annual forum for discussions at ministerial level, is a regular source of fresh initiatives, including the notion of 'food strategies', which have received wide acceptance as a way of giving a constructive and coherent focus to agricultural and food policy at a national level [eg WFC 1980].

These agencies do not, however, have the field to themselves. Perhaps the most influential critic of food aid has been the Chicago economist and Nobel laureate, T. W. Schultz [1960], who questioned the cost-effectiveness of food transfers and outlined the possible disincentive effects on agriculture in underdeveloped countries. There is no dearth of recent critics of food aid, its effects and the motives of its donors, among them Susan George (How the Other Half Dies [1976]), Colin Tudge (The Famine Business [1977]) and the Lappé and Collins team, who followed their first attack on the 'ten myths' of world hunger (1977) with Food First: Beyond the Myth of Scarcity [1979] and Aid as Obstacle [1980].

\section{Project Food Aid}

One of the most tireless critics of food aid and food aid donors is Oxfam's Tony Jackson, whose recent book [1982] decries particularly project aid: commodities supplied for use in public works (particularly food for work) and nutrition schemes (mainly school feeding and mother and child health). The conclusion of Christopher Stevens, 'a curate's egg, good in parts' in his study of project aid to four African countries applies to much of the project impact literature. The majority of food-aided projects are managed by the World Food Programme (WFP), whose activities are considered by Wallerstein [1980], Cathie [1982] and by Dawson [1981], the former Head of WFP Evaluation Services. Others who have reviewed the evidence of evaluations of food for work and nutrition projects are Maxwell [1978], Gilmore [1980], Mellor [1980], Capone [1980], Guha [1981] and Austin [1981]. The last two do not deal specifically with foodaided schemes, but with nutrition programmes and rural public works in general, but they offer lessons on the design of food aided projects.

Much detailed analysis of food aided projects has been at individual country level, for example in Bangladesh (see Nelson's article in this Bulletin). Here the literature falls into two parts. Before 1971, when food aid commodities were sold on the market in Bangladesh to generate funds for paying the project workers in cash: Sobhan [1968], Thomas [1971] and Khan [1971] looked at these rural public works. After the introduction of food for work (FFW) in 1972, the literature examined, specifically and critically, food aid itself. As well as the more polemical attacks by outside observers [Jackson 1982, Henshaw 1980], Brundin [1978] has attempted to estimate the scope for FFW programmes. The Bangladeshi Institute of Nutrition and Food Science [University of Dacca 1978] examined the economic and nutritional effects of FFW; the Bangladesh Rural Advancement Committee (BRAC), in its publication The Net [1979/80] also highlighted the problems, such as corruption, associated with food for work. The Bangladesh Institute of Development Studies is cooperating with the International Food Policy Research Institute on a major study of food for work projects in Bangladesh, which should be published in 1983.

\section{The Donor Agencies}

Complementing the findings by outside analysts are the internal reviews carried out by donor governments, many of them unpublished. The most extensive literature emanates from the United States, the major donor. The Food for Peace annual review gives the official picture of USAID's programme. Other recent reports have included one by the US Senate [1978] on new directions for US food assistance and the examination by Clay and Singer [1982] of the impact of PL 480 Title I (programme) type assistance. US food aid policy issues are also aired in the Agricultural Development Council's 1979 report of its seminar on 
the implementation of PL 480 Title III, and the USAID's own policy discussion paper [1981].

The EEC's food aid programme is considerably younger, but it has already generated an institutional literature. In addition to the report to the European Parliament and related debates, already mentioned, a study was commissioned from ISMOG at Amsterdam University [1977], summarised in Bos [1978]. The Community's Court of Auditors published a special report on food aid in 1980. Two further studies were commissioned, on the cost and value of Community aid (by the IDS/CEAS team from Sussex University and the University of London in 1981), and an evaluation of its impact (by the Africa Bureau Cologne/IDS in 1982). Other perspectives on Community food aid policy are provided by Delorme [1977] and Talbot [1979].

The policy issues underlying Canada's and Australia's food aid programmes have not received a comparable airing. Cohn [1979] looked at the domestic and foreign implications of Canada's food aid, but the main source of information on the programme is the Canadian International Development Agency. This produces an annual review with statistical appendix [latest CIDA 1982] and occasional publications [eg CIDA 1980]. The Australian Development Assistance Bureau has issued a Fact Sheet on food aid [ADAB 1978] and occasional unpublished memoranda, including one [ADAB 1982] on its allocation of food aid. Statistical details are included in ADAB's annual Statistical Summary of Australian Official Development Assistance to Developing Countries.
In contrast with such national food aid agencies, the WFP's activities and policies, as well as receiving widespread publicity [eg Wallerstein 1980; Stevens 1979; Cathie 1982] are minutely documented in a massive internal literature prepared for the Committee on Food Aid Policies and Programmes (CFA), which supervises its acitivities. For example the annual Review of Food Aid Policies and Programmes [latest WFP 1982] and Food Aid Requirements and Targets in the Eighties [WFP 1979].

\section{Statistical sources}

The Organisation for Economic Cooperation and Development (OECD) reports food aid in monetary equivalent in its annual Development Cooperation review (see article by Clay, Table 1). The FAO also publishes a quarterly Food Aid Bulletin which is a principal source of statistics on food aid in cereals and EEC dairy transfers (see article by Clay, Tables 2 and 3). However, both series are incomplete: the $F A O$ Bulletin does not record concessional supplies of food from the Eastern bloc's Council for Mutual Economic Cooperation, and the OECD review only covers OECD members of the Development Assistance Committee (DAC). A forthcoming monograph by Huddleston (due to be published by IFPRI in 1983) discusses in detail the problems of assembling comprehensive figures for food aid deliveries, and will contain the most comprehensive statistical survey so far of deliveries of food aid cereals, covering the two decades from 1961 . 